\title{
Women Empowerment: Current Insights and Debates
}

\author{
Seema Mehra Parihar ${ }^{* 1}$, Tapati Bannerjee ${ }^{2}$ \\ ${ }^{1}$ Associate Professor, Department of Geography, Kirori Mal College, University of Delhi \\ ${ }^{2}$ Director, National Atlas Thematic Mapping Organisation (NATMO), India
}

Corresponding author: Seema Mehra Parihar; smparihar@kmc.du.ac.in

Received: December 19, 2020;

Accepted: December 27, 2020;

Published: 19 January 2021

\begin{abstract}
Women empowerment even today is as important as it was ever before. This paper delves into a few current debates and an approach, highlighting that engagement with actions required towards women empowerment is necessary and relevant. Meeting with women empowerment demands a sensitive driver who understands its relevance and is ready to pull and push measures with passion. The paper highlights that if we focus on the idea of women empowerment, we must ask ourselves what it means in terms of a socio-economic, sociopolitical, or, put, the social reality of gender parity in our societies and around the world as well. Empowerment for a person would, at a basic level, mean the person's fundamental ability to have power or control of their own lives concerning the fundamental rights and freedom that every person is entitled to. So, in a broad sense, women empowerment would mean helping empower women to be independent and have more control over their own lives. This paper is based on observations, literature review, and multiple interactions, including data collected through structured and unstructured questionnaire surveys. Writing this paper was to understand the social space that women occupy before delineating the framework for ' Women Empowerment Atlas Project'** and suggest ways to uplift their status in society. Science and technology as mediums can help raise awareness among women and aid them in myriad ways and empower them with multiple livelihood opportunities, besides exhibiting the possibility of women safe gadgets which, thereby evolving safe spaces and ecosystem.
\end{abstract}

Keywords: Women empowerment, education, employment, Science and Technology, gender parity

\section{Introduction}

When we focus on the idea of women empowerment, we must ask ourselves what it means in terms of a socio-economic, sociopolitical, or, put, the social reality we see around us in our societies and around the world. Empowerment for a person would, at a basic level, mean the person's fundamental ability to have power or control of their own lives concerning the fundamental rights and freedom that every person should be entitled to. So, in a broad sense, women empowerment would mean helping empower women to be independent and have more control over their own lives. Science and technology as mediums can help raise awareness among women and aid them in myriad ways, for example, getting accessible education or secure jobs, both through online and offline mediums. Thus, while focusing on the topic of women empowerment in India, we must look at factors such as the overall employment status of women in India, their level of education or qualifications, and the gender gap of work participation rate to give us a broader idea of what their status in society is and also go on to understand why such factors play a crucial role in empowering or uplifting women. The themes mentioned below may look at places ad-hoc, but what binds is the wish for urging us to ponder, have we understood the meaning of women empowerment?

\section{Methodology}

The first step in the research process, concerning data collection, originated from a close reading of various research works and arguments. The data so collected was qualitative as well as quantitative to meet the objective of the study. We made sure to collect data from credible and reliable sources. This was facilitated by analyzing published works along with archival data. With the Delphi method's help, we rearranged our arguments and listed the relevant themes even today and currently create challenges while striving for women empowerment. Data collection geared us toward a more holistic and comprehensive study.

\section{Discussion}

\section{Women's Participation in Labor Force}

The current global labor force participation rate (LFPR) for women in India is lower for women by around $50 \%$. For men, it is $78.8 \%$. For women, it is close to $27.2 \%$ (Figure 1). This variation is attributed to different factors ranging from patriarchy, mindset and, existing social structures, cultural norms, and many discriminatory practices. However, this data is lower when we consider WPR data found on TUS based estimates (11.4\%) and NSSO (28.9\%), and Census-based forecast $(26.2 \%)$. 


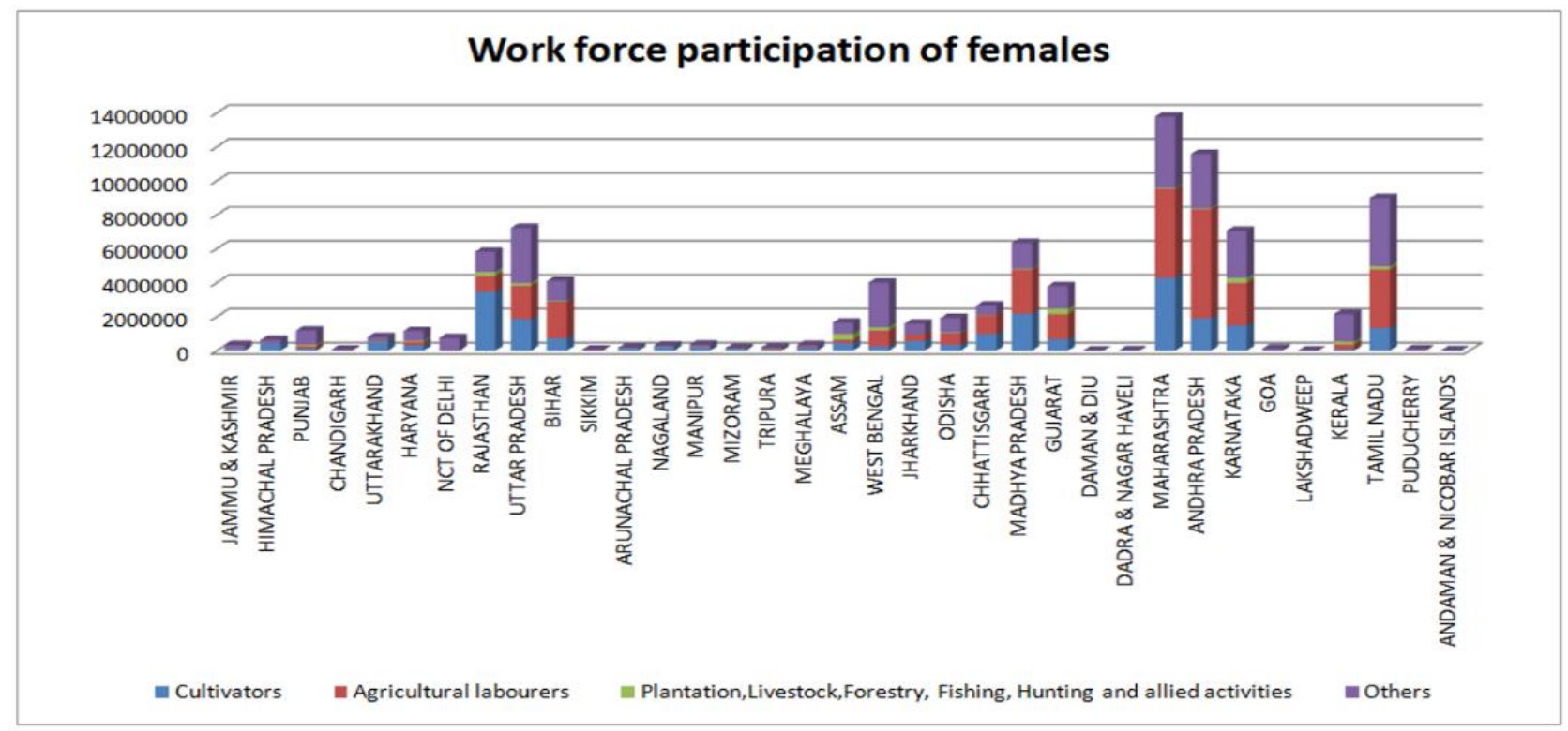

Figure 1: Workforce Participation of females in India (Based on Census of India data2011)

Despite educational advantages in terms of rising education among women (Table 1), women's literacy rates had increased from 1951 $(16.83 \%)$ to $2011(65.46 \%)$ in 2011 . India, the world's largest democracy, would have been 27 percent richer if women had participated in the labor market at the same rate as men. It is a disturbing trend that almost the whole of their salary, definitely more than $90 \%$, women invest in their families and communities. Gender bias in labor force participation is a critical economic challenge. To increase WPR, there are several drivers, and foremost is educational attainment, urbanization, age of marriage, and cyclical effects of economic growth.

\section{Stable and Secure jobs for women}

An important aspect to consider is the factors that can empower women to control their own lives and be independent, for example, making decisions that impact their own lives. One of the most critical aspects concerning a woman being empowered would be to be employed with a secure and stable job. Women even today, as seen during COVID 19 pandemic, are generally overrepresented in low paying $(76 \%)$, part-time $(68 \%)$, informal ( $71 \%)$, and low productive jobs $(73 \%)$. As expected by all, what is required is a stable job which is safe and productive too. If more and more women are not participating in the country's workforce, they would have to depend on their husbands or other family members for economic support, who may influence them accordingly.

Further, a woman may not want to divorce her husband, even on being a victim of domestic violence or harassment, because she does not know how to manage her own life without her husband's support. He turns out to be the sole breadwinner in the family. She cannot in these situations depend on her parents for economic support after a divorce, as they may themselves be old and retired. Thus, in such cases, the woman ends up being at the mercy of the ones she is economically dependent upon. Hence, a woman may not have much control over many significant aspects of her own life and overall well-being.

\section{INDIA : WOMEN IN HIGHER EDUCATION}
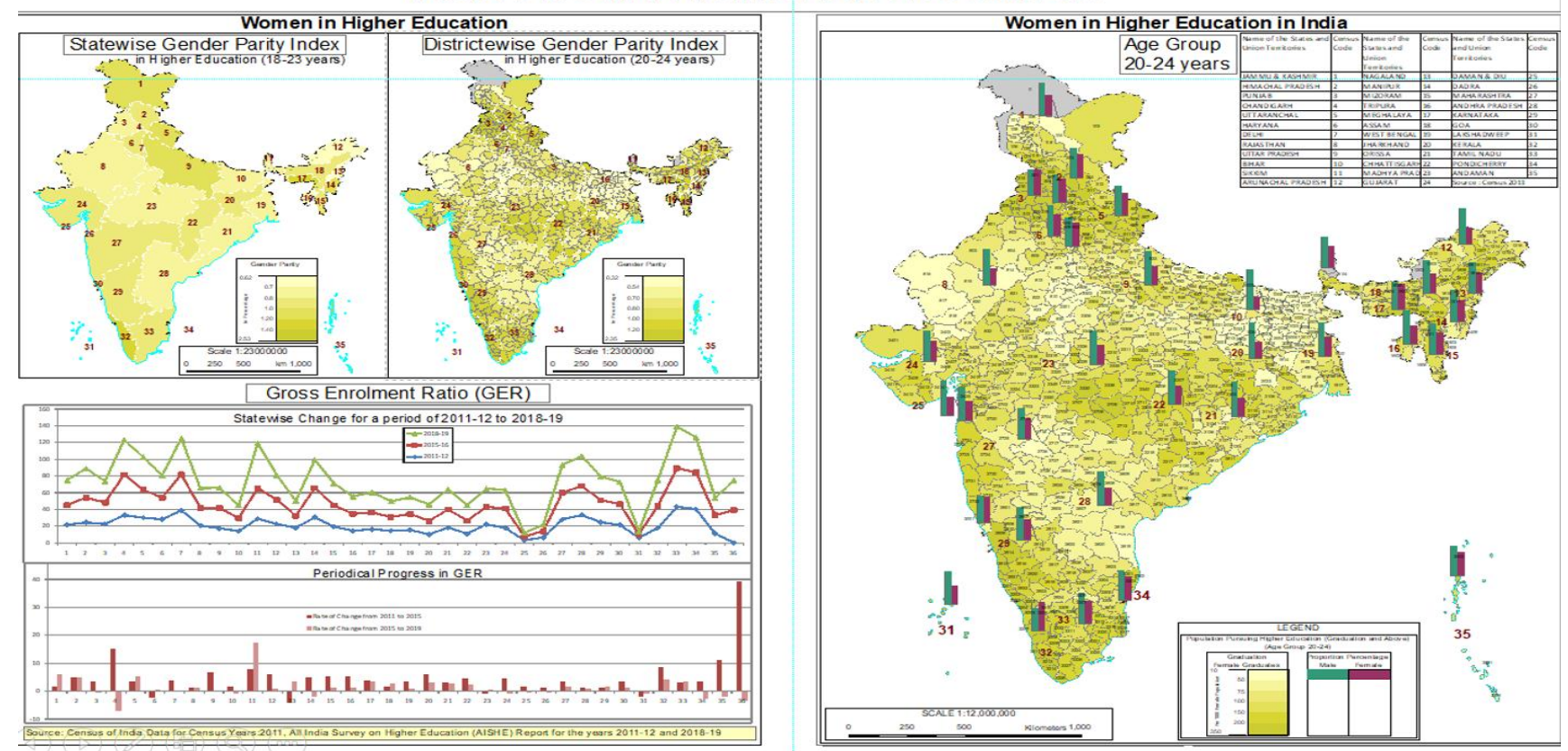

Figure 2: India: Women in Higher Education (2011-2012 \& 2018-2019) 


\section{Women's Education}

Those women who might have the chance of a healthier and happier life should be reason enough for promoting girls' education. Figure 2 illustrates the statewise Gender parity index and district-wise Gender Parity Index, highlighting low parity for women. This anomaly has to be reduced. Moreover, there are also significant benefits to society. Self-confidence with new skills and information can enhance the performance of all women. They will be a better parent and worker. Some studies have indicated that one extra year of education can increase women's earnings by around $5 \%$ than men's.

Table 1: Level of Education: Male \& Female

\begin{tabular}{|l|l|l|l|l|l|l|}
\hline \multirow{2}{*}{ Level of education } & \multicolumn{2}{l|}{ Absolute Numbers $\left(000^{\prime}\right)$} & \multicolumn{2}{l|}{ Percent to Literate } \\
\cline { 2 - 6 } & Persons & Males & Females & Persons & Males & Females \\
\hline Literate & 560,688 & 336,534 & 224,154 & 100.0 & 100.0 & 100.0 \\
\hline Literate without educational level \$ & 20,023 & 11,361 & 8,662 & 3.6 & 3.4 & 3.9 \\
\hline Below Primary & 144,831 & 81,148 & 63,683 & 25.8 & 24.1 & 28.4 \\
\hline Primary & 146,740 & 83,525 & 63,215 & 26.2 & 24.8 & 28.2 \\
\hline Middle & 90,227 & 55,940 & 34,286 & 16.1 & 16.6 & 15.3 \\
\hline Matriculation/Secondary & 79,230 & 51,202 & 28,028 & 14.1 & 15.2 & 12.5 \\
\hline High secondary/ Intermediate/PreUnivercity/ Senior Secondary & 37,816 & 24,596 & 13,220 & 6.7 & 7.3 & 5.9 \\
\hline Non-technical diploma or certificate not equal to a degree & 386 & 259 & 128 & 0.1 & 0.1 & 0.1 \\
\hline Diploma-technical or certificate not equal to a degree & 3,667 & 2,901 & 766 & 0.7 & 0.9 & 0.3 \\
\hline Graduate and above & 37,670 & 25,533 & 12,137 & 6.7 & 7.6 & 5.4 \\
\hline
\end{tabular}

So, to help more women be employed in India would ensure that they can control their lives.

\section{Low Participation of Women and Indian workforce}

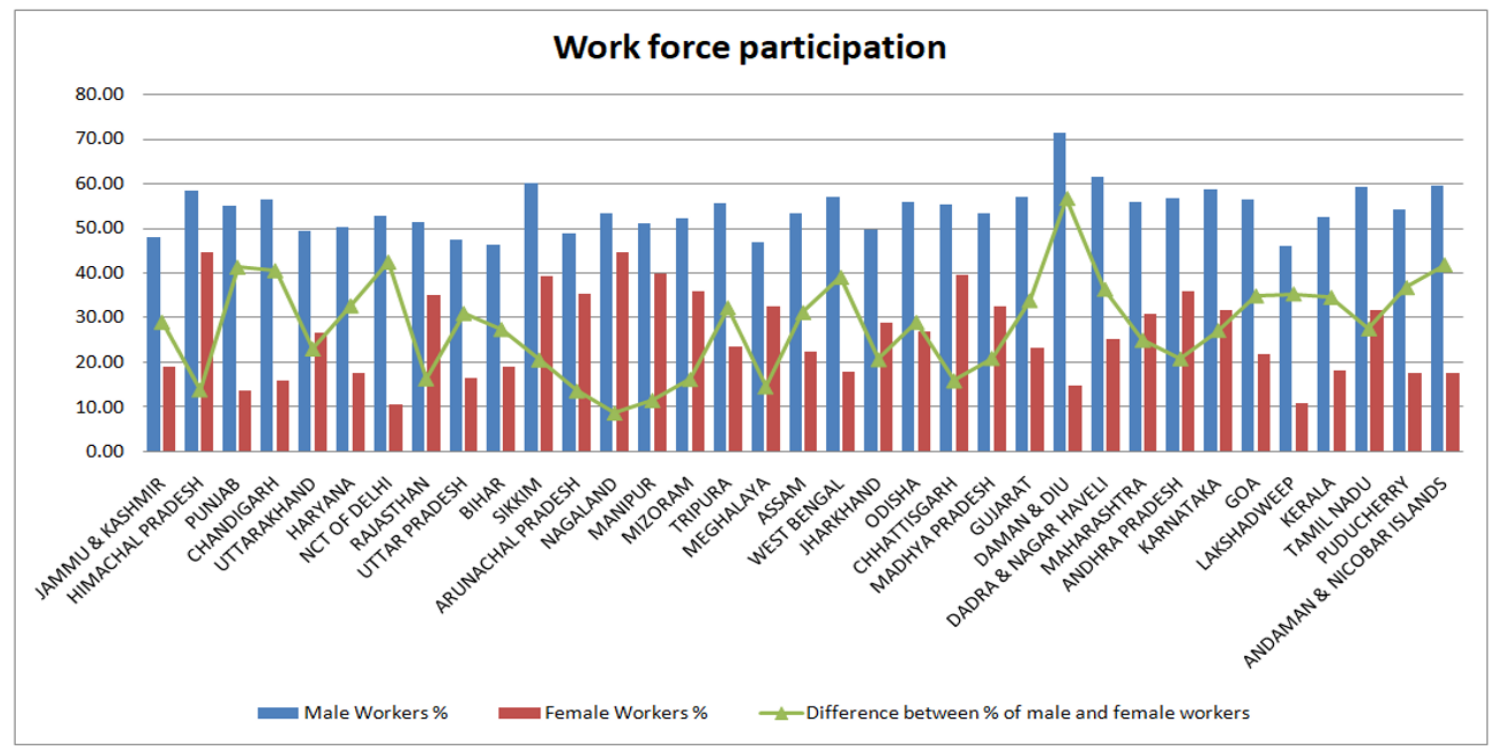

Figure 3: Workforce participation in India (Based on Census of India data2011)

It is essential to consider that women's workforce participation in India (figure 3 ) is the lowest globally in both its rural and urban sectors. There can be many factors as to why this is the case, ranging from social aspects to gender inequality factors at the workplace. So, let us analyze some of these factors. The first reason for this can be attributed to India's social factors, like the patriarchal nature of Indian society, which does not allow women to work outside the house and believes in having women spend as much time as possible indoors. The patriarchal notion follows that the men should look for work while the woman is seen generally as a person who should take on the caretaker's role and family. This happens to working-class women in India as well, who already are working. When burdened with managing the household, many-atime cannot take the pressure and quit their jobs, resulting in women's workforce participation further declining in India. If more women did pay work, India's value would rise dramatically. GDP will also be affected by toa range of $20-25 \%$, as shown in different data.

On the one hand, we are talking about increasing LFPR, but reality depicts a gap of around 15\% from 1994 (35.8\%) to 2012 (20.2\%). Further, for casual workers or self-employed, LFPR is less than 10\%. At the global level again, India lags with LFPR in Sweden $(88 \%)$, and the world average is $40 \%$. There are few exceptions, like $11.7 \%$ of India's 5,100 pilots are women, against a worldwide average of three. Recently Air India's all-women crew created history with their longest direct flight from San-Fransisco, US to Bengaluru. Another positive data is of LFPR in MGNREGA (Mahatma Gandhi National Rural Employment Guarantee Act) with fifty percent presence of women. To note is the dismal 120 rank of women in LFPR among 131 countries; security reasons can be why women do not choose to join the workforce in India. A lack of secure spaces and environments to work, especially for women from the low-income to below-the-poverty-line brackets of society.

On the one hand, women are joining more jobs, but at the same time are nowadays recording more cases of sexual harassment. There is a spatial variation, but multiple readings highlight that more than $80 \%$ of women come across different types of sexual harassment. This leads to anxiety and depression and sometimes forces women to quit. Sexual harassment in the workplace cannot be ignored. Women are the majority of the needy thanks to developmental patterns and values, gendered categories of resources, and potential changes between men and females. Indeed, 
women and girls bear an uneven burden of unpaid domestic responsibilities and are overrepresented in informal and insecure jobs.

This may cause women to quit and look for another job or ways to be employed. Another critical factor towards women not being used at a given point in India may be the demand skill mismatch. What industry or employers demand from an employee may be different from the skill set they possess. These factors influence women's employment status in India's urban and rural sectors as factors like social factors, security reasons, gender inequality, etc., play a considerable part.

\section{The active female population in the agricultural sector}

Considering the socio-economic infrastructure of rural India and that many professions that come up in rural India are linked to the agriculture-based rural economy and also considering that a large part of our population depends on the agricultural sector directly or indirectly for their income, we need to see how women end up being or not being part of the employed workforce in rural parts of the country as well. Many families depend on agriculture as their income source and often expect and make them work in the fields to help. A lot of the women in India do engage themselves in subsistence-level agricultural work. They engage in agricultural activities, but they cannot be considered employed as most of them do not get paid for their work. Available data illustrates that around three-fourth of the agricultural labor force in developing countries are women.

\section{Digital Science and Technology courses for women}

Let us see how science and technology can help increase women's participation in favorable government policies, empower women, and help them find jobs. For example, the internet can help many household women, who have been educated till even the 10th or 12th-grade levels of school education in India, take up courses online, enabling them to get jobs and have the skills required by employers industries. Institutes and companies themselves may also set up these online courses. Digitalization has allowed many females to leverage technology-based solutions, but mostly this has increased the gender gap. A global study highlighting women's importance in agriculture and other sectors is to gain insight into where female farmers sit within the agricultural and infrastructural value chain. Those evaluated said that they need more training. To clarify that if technology has improved for women in agriculture, yes, it has. However, many women worldwide are still unable to access such technology; online courses such as Innovation in Arable Farming: Technologies for Sustainable Farming Systems (Future Learn) are also being used, and data is motivating. Drones for Agriculture Introduction to Sustainability (Coursera), Climate Adaptation in Africa (Coursera) are a few courses that help women learn things about agriculture. Still, some of them, being poor and belonging to rural areas, are unable to access the internet.

\section{Technological Advancement for Women Empowerment}

The induction of technology and access to it has considerably elevated the process of women empowerment globally. Technology has come up with innovative and prominent methods to counter the upheavals faced by women, whether in equating society's gender gap or extensive access of women's education in developed and undeveloped areas, upgrading the personal healthcare infrastructure and their connection with the health experts and improving safety. All the key features of women empowerment are identified and aimed at in the most efficient manner through Technology usage.
The challenges faced by rural women are far more adverse, as they face a triple divide of digital, rural, and gender. However, the positive impact of technology on women's rural population has been significant in most cases. The delivery of favorable information and schemes seemed impossible due to linguistic diversity in nations like India. However, nowadays, it has become very convenient for the Government to reach out to most of the rural population of women in their respective local languages because technology enables them to do so. Technology utilization has helped spread awareness amongst rural women regarding their health and hygiene and their menstrual health. Nearly 60,000 women die of diseases due to poor menstrual hygiene. Over 23 million girls drop out of their schools when they begin menstruating due to the prevailing myths in society regarding menstruation hindering women's education and empowerment. To this avail, the Government has been quite successful in spreading awareness regarding menstrual health through the internet. Safety was one of the significant challenges for the women themselves and the Government and society. India is a patriarchal and orthodox country where women are the victims of innumerable crimes and malpractices, ranging from rapes to child marriages. Although technology might not have fully satisfied or guaranteed safety to women, it has undoubtedly been advantageous in many situations and is a stepping stone towards women's safety.

One such technology utilization is the "Himmat" app, a women safety mobile application of the Delhi Police launched by the Home Minister in 2015, which acts like an emergency service where distressed women can send a distressed call. Also, 114 apps were introduced and launched by the Government in 2019 to curb widespread violence against women. Technology has targeted the education of women of every age group in rural areas. It has built a safe environment and a convenient platform for them to access education easily. It is now possible for women from different age groups to access education digitally, thereby combining their daily work without letting their education get affected. Even though technology has played a vital role in spreading education among rural women, it has failed in several places. There are a few obstacles that hinder the way to take advantage of technology in rural areas.

A wide range of initiatives and services are being launched throughout India, which enable women to connect with the internet and technology. This process has allowed women to develop and open startups using a limited number of available resources. "Google Saathi" is one such initiative launched by Google in collaboration with the Indian Government, which aims at educating rural women through the internet. This initiative enables these women to benefit from the internet and helps them in their daily activities. Under this scheme, rural women are appointed to technically skilled women who act as ambassadors or guides and are named "Saathi"(Friend). These Saathi's guide and teach rural women to operate the internet. This initiative has successfully targeted over 2 million women in the rural areas of ten states in India.

\section{Science \& Technology and Women's Safety Apps:}

Science and technology have empowered women of today with the following Apps working towards Women's Safety. However, even today, the critical question is that women are accessing them and using them or even aware of them. Analysis of around 500 questionnaires has led us to believe that currently, it is less than 20 $\%$ who are aware of half of the following mentioned 22 Women's safety applications (Figure 4). 


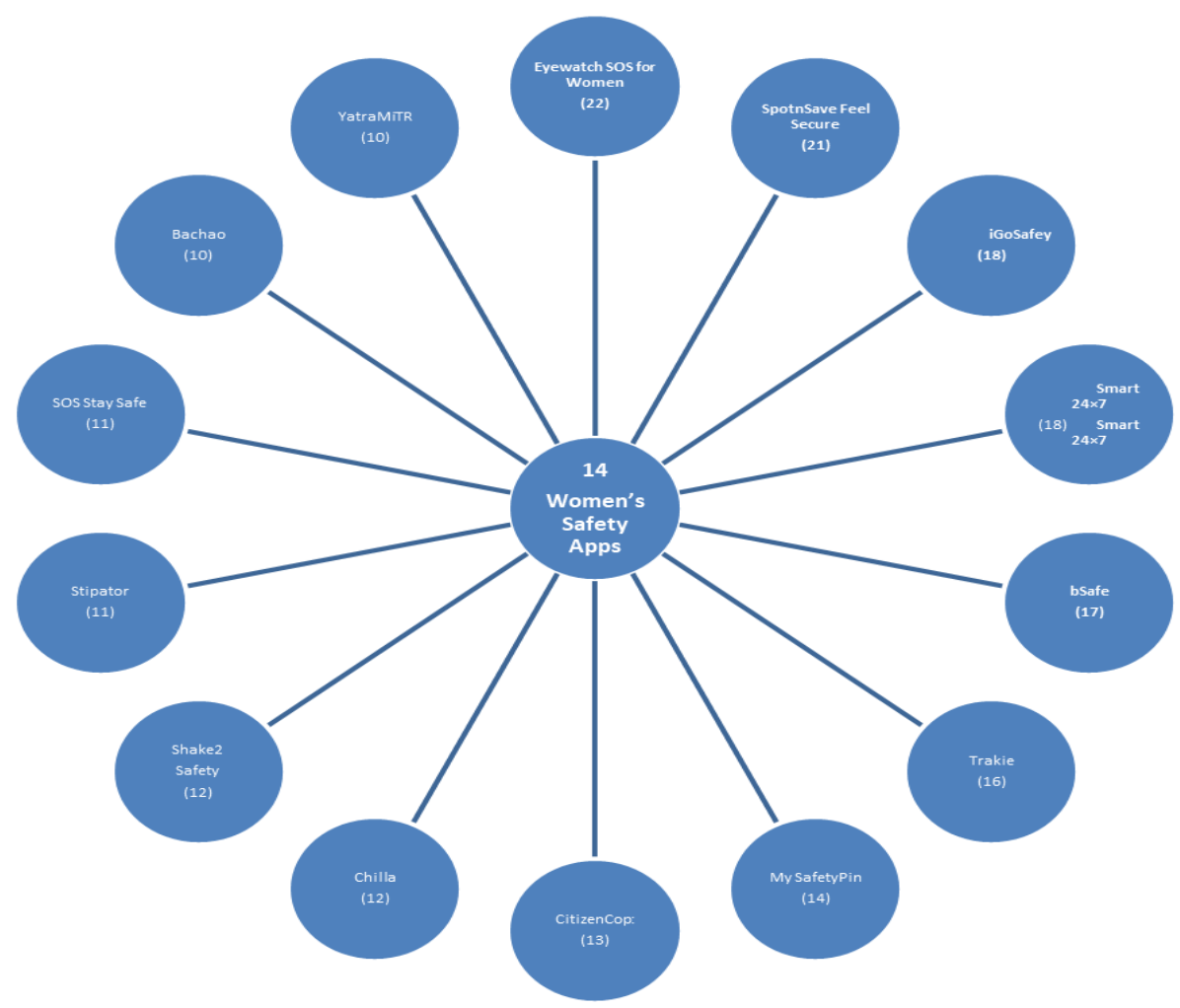

Figure 4: Fourteen Women Safety Apps with parentheses denoting the low awareness level by women

Table 2: Selected Women Safety Apps used by more than $10 \%$ of the Women

\begin{tabular}{|c|c|c|c|}
\hline S.No. & App for Women & Relevance for Women safety & Awareness Level \\
\hline 1 & $\begin{array}{l}\text { Eyewatch SOS } \\
\text { for Women }\end{array}$ & Captures the neighborhood surrounding and send alert message to the registered contact. & $22 \%$ \\
\hline 2 & $\begin{array}{l}\text { SpotnSave Feel } \\
\text { secure }\end{array}$ & Feel secure creates an alert message every two minutes & $21 \%$ \\
\hline 3. & iGoSafely & By shaking the phone, send an alert message along with a 30Second audio recording. & $18 \%$ \\
\hline 4 & Smart 24×7 & Helps the user to call a police through embedded panic button. & $18 \%$ \\
\hline 5 & bSafe & Allows calling the previously dialed number and send an SOS alert by shaking the phone. & $17 \%$ \\
\hline 6 & Tracker & Provide real-time information \&secured with OTP and SIM number feature & $16 \%$ \\
\hline 7 & My SafetyPin & Send alerts at crossroads to family and friends. & $14 \%$ \\
\hline 8. & CitizenCop & Anonymously alert any thefts, robbery, or any illegal activity and create a Safe Zone. & $13 \%$ \\
\hline 9 & Chilla & $\begin{array}{l}\text { Get activated by mere shouting and send alert messages and pressing the power button } 5 \\
\text { times pre-configured contactacts get alerts. }\end{array}$ & $12 \%$ \\
\hline 10 & Shake2Safety & $\begin{array}{l}\text { Send SOS message both by shaking and pressing the power button } 4 \text { times without an } \\
\text { internet connection and locked screen }\end{array}$ & $12 \%$ \\
\hline 11 & Stipator & Through popular social networks act like a bodyguard. & $11 \%$ \\
\hline 12 & SOS Stay Safe & Real-time GPS enabled tracking system & $11 \%$ \\
\hline 13 & Bachao & Send messages to trusted friend while traveling late /outstation. & $10 \%$ \\
\hline 14 & YatraMiTR & Location can be located even on the Portal of Yatra Mitr about Live locations. & $10 \%$ \\
\hline \multicolumn{4}{|c|}{ HEALTH } \\
\hline$\underline{15}$ & $\begin{array}{l}\text { Mother's } \\
\text { World: }\end{array}$ & $\begin{array}{l}\text { Personalized pregnancy app that informs about pregnancy progression and is endorsed by } \\
\text { medical experts. }\end{array}$ & $11 \%$ \\
\hline 16 & Nine Minutes: & $\begin{array}{l}\text { An app that provides a game experience by providing healthy choices all along nine months } \\
\text { and making them look nine minutes }\end{array}$ & $6 \%$ \\
\hline 17 & $\begin{array}{l}\text { Period Tracker } \\
\text { (Pink Pad): }\end{array}$ & Helps in marking your period dates and track the menstrual cycle. ? & $5 \%$ \\
\hline
\end{tabular}

Moreover, technology can also increase women's security outside their homes in India and make them feel more secure in stepping outside their houses to search for work. This can be done by lighting up more public places at night and installing more CCTV cameras in public areas for women's safety and reliable public transportation to help them transit between their homes and workplaces. This is where government policies can help to ensure that these services are accessible. Also, in rural areas where women already set up self-help groups to assist them in having their source of income, science and technology can provide them better tools through machines that may increase their productivity and transportation and connect to more places to expand their business. Government policies to help ensure women get paid as much as men in workplaces can also encourage women to join the 
workforce or continue to be a part of it. Even in government policies like the National Policy for Farmers, more women should be recognized as farmers to access inputs, credits, and market and extension services. Government policies that help address and curb down the structural aspects of our society and economy that lead to a lower workforce participation rate for women should be implemented.

\section{Gender stereotypes}

Another predominant factor that plays a prominent role in women's empowerment are reflected in social attitudes at the workplace. Gender disparity manifests itself in many forms. Most common of them all being the trend of social stereotyping, acute wage differentials of men and women for the same work, and discrimination at the workplace.

According to various surveys conducted by different organizations and institutes, the work participation rate of men is exceptionally more significant than that of women. This extensive polarity in the work participation rate is mostly due to gender stereotypes.

The Indian Government, no doubt, has made different policies and programs so that they could bridge the gender gap of work participation. The Government has also come up with many ventures that are downrightly aimed at furnishing underprivileged women with jobs, strengthening women's movement in the informal economy by highlighting their issues and bringing them to the national level employment be self-reliant.

\section{SEWA Bharat Program and other such schemes}

One such scheme is the SEWA Bharat Program. This program aims at empowering women in India so that they could be selfreliant and economically sound with their needs fulfilled, such as employment, nutrition, income, healthcare, housing, education, childcare, etc. The SEWA Bharat scheme has impacted many women's livelihoods in the agricultural sector, giving them increased income and production than before by organizing training sessions and providing them with technology. The implementation of SEWA Bharat has been done through many programs such as organic masala production, Almora in Uttarakhand, the right to free and compulsory education act in the Jaipur district of Rajasthan, SEWA Munger's incense production, Katihar in Bihar, organizing into SHG'S (self-help groups) in Bareilly, Uttar Pradesh, etc.
The problem that needs to be sought after is how far such ventures and programs initiated by the Government are advantageous for women and the magnitude of these programs work. These programs provide employment opportunities to women, help them achieve their goals by providing them with the required amount of education and practice in particular sectors, and enhance their working skills according to the workplace requirements. These programs fail to acknowledge the different barriers ingrained in the people's minds through India's cultural norms that make it difficult for the women of the lower levels of society to be self-sufficient and reliant. Some other factors that go unnoticed are women's exploitation by releasing personal information about them, cyberstalking, unfair hiring practices, harassing, career progression, online pornography, unequal pay for men and women, and flaming. Sexual harassment appears to be a manifestation of unequal power relations between men and women at the workplace.

\section{Online aid to empower women concerning science and technology}

Technology has emerged as a panacea for the ordeals, as mentioned earlier. In the 21 st century, the growing access to the internet has allowed women to empower themselves by using the internet as a tool. The pre-eminent social networking sites like Facebook, Instagram, and Twitter are being used by women today for online activism. Through this, women can voice their opinions and ordeals and campaigns for equal rights without being oppressed by other society members. Blogging has become a mighty tool for the educational empowerment of women. Another bright side of this technology is that women who cannot attend classes can educate themselves and plan strategies to expand their working endeavors. Schemes such as Mahila e-haat announced in march 2016 or methods like Nari Shakti Purusakr, introduced in 1999, or recently introduced Make on India and Stand -Up India or existing National Credit Fund Women (NCFW), which together can lead to women empowerment.

\section{Marginal Increment of women in STEM subjects}

Another issue to be discussed is that women currently have a minimal presence in science and technology. Over the decades, this presence has increased but only at a very marginal rate. This data (figure 4) gives us a brief idea of how women have risen from a minimal presence to a marginal increase in respect to science and technology over the past few years: -

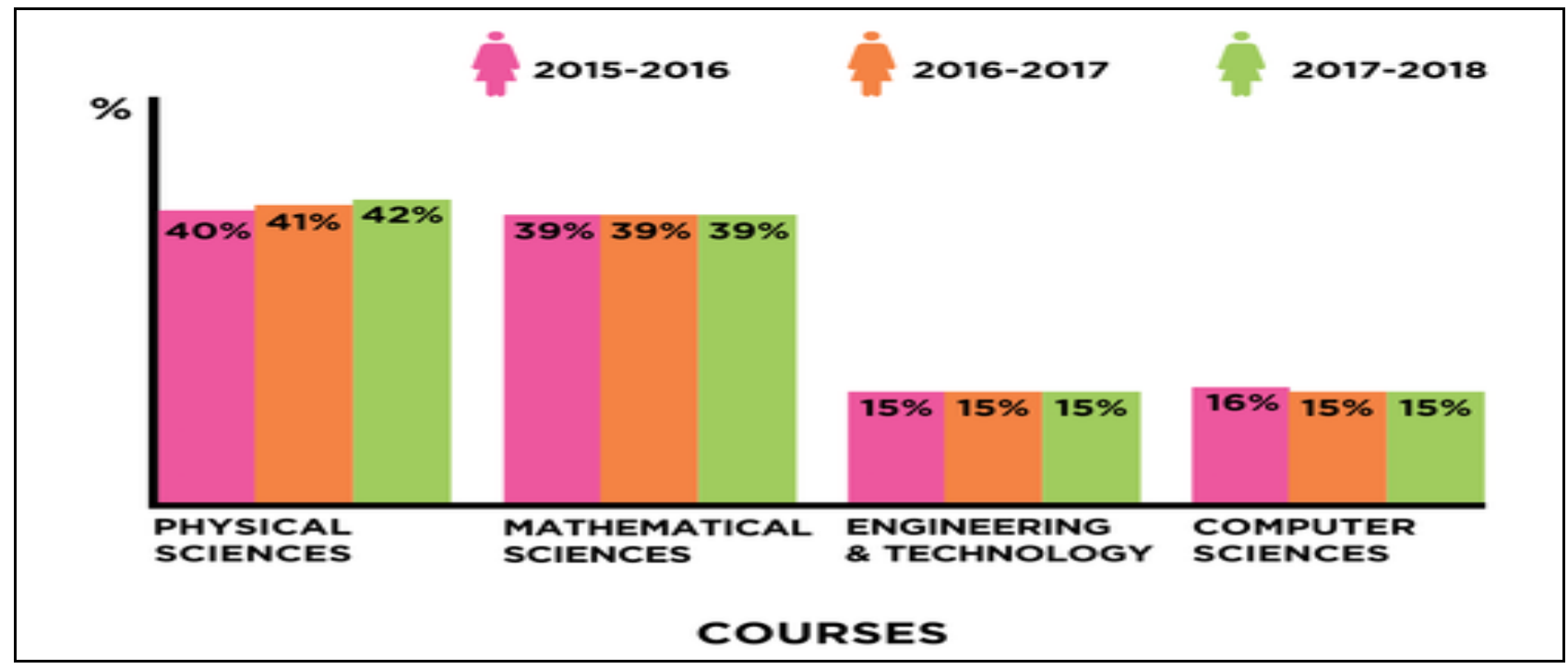

Figure 4: Presence of Women in Science and Technology Courses 
Significantly developed nations such as Sweden to extremely impoverished ones such as Sierra Leone see little differentiation in women's science and technology participation. The factors include one, women's perceptions. Understanding the role they play in society is shaped by patriarchal structures that further strain the ability and capacity to perform well. Secondly, women's societal expectation is a burdening factor, as well. Women's intellectual endeavors are additionally overly burdened by domestic responsibilities reinforced as a result of societal responsibilities. Family commitments have historically impaired the ability of women to succeed in fields of science and technology.

Education can be seen as a primary index that all humans, irrespective of socio-economic abilities, are entitled to receive. It is one of the most critical and essential tools to reduce the disparities between men and women. Technology innovation can further educational methods while also creating educational and entrepreneurial opportunities for women at the grassroots level. To make sure that women succeed in science and technology, such support structures must be developed both societal and institutionally that assist and encourage science as a viable career option for women while rewarding a positive societal attitude that encourages the same. Science and technology increase the choices available to any individual to succeed and enjoy life to the fullest potential. This creation of an option is exceptionally vital in preserving the ideals of liberty and freedom and ensuring the persistence of a dignified life.

\section{Historical Reference of Women's active participation in Science and Technology}

The ideas of women's participation in science and technology have birthed and grown in Indian society for more than a millennium. Women are seen as critical thinkers all around the world. Providing access to science and mathematics to these women will facilitate extreme progress. However, to ensure that women consider a career in science as viable and as essential as other domestic tasks that society has enforced onto them, we need to ensure that women feel a career in science as feasible and as necessary as other household tasks. It is only that women comprise $40 \%$ of the students pursuing science in undergraduate courses. Finally, in today's times, ' women in India are slowly gaining socio-political influence because of the convergence of science and technology to lift women out of patriarchal structures. Hence, it is noted that modern Indian women have more decision-making power and higher incomes than they held in the past.

\section{Social Changes}

We need to understand that societal change is a pain-staking process that involves decades of continuous efforts. Thus, if we instill the values of gender equality now, we could see transformational change in women's societal conditions within a few decades. Unlike other global democracies, women in India have had a right to vote since Independence.

This has primarily resulted from the reach of science and technology that has pierced the very heart of such patriarchal structures, providing women with a chance at intellectual liberation. To increase employment opportunities for women in science and technology, we need to focus on the institutional reason for the existence and slowly evolving it from creating destructive weapons to solving societal issues before all. This would place additional focus on science and Technology's role to solve women's problems by female scientists and peers. This is backed by research by several experts that women are more interested in ethics than men. In India, men's literacy rate is double that of women, with less than two million interred connections, and very few schools' women rarely get access to education. However, as a positive indicator, women's involvement in the tech field is continually growing. The graduation rates from leading technological institutes and the nation's largest specialized firms' hiring data show a steady increase in women's participation. According to a study carried out, over 200,000 women graduated from STEM fields in 2016 compared to just over 140,000 in 2009.

\section{The 'trickle-down theory' with regards to women's participation}

As discussed before, employment empowers. The women are the oppressed in typical patriarchal society, and employing them would be one of the best factors to apply the theory of "trickledown power" because a powerful woman can become a role model and inspiration for the other women at the lower level as well, more so they will be able to bring up problem faced by the women in general as who else is better to understand a problem than the person who has gone through it them continually the application of this theory will empower the entire society. Employment for women, especially in science and technology, would result in empowerment in several realms, including personal, financial, and political.

\section{Legal and Economic Developments}

Providing legislation that creates employment for women at a microeconomic scale, such as the panchayats in India, could be an extremely beneficial policy decision that could empower women.

Thus, women should be encouraged in science and Technology to address issues of gender disparity and as a tool for national economic development. As women are both producers and consumers in an economy, they must play a role in all eco-political decisions. Additionally, to further the participation of women in science and technology policies that bring to the forefront, all issues of systematic and institutionalized sexism that always affect women must be exposed, and assistance must be provided to women to succeed to their fullest potential. The Government can create this by creating a localized societal and educational infrastructure that provides thorough nurturing of a scientific women's mind by providing excellent education and employment opportunities. This should be coupled with anti-discrimination policies that prevent companies from hiring based on gender and sex and penalizing them. If such measures are taken, only then can we ensure that after centuries of women lagging behind men, they can finally lead the world to a sustainable future.

\section{Conclusion}

Today, women empowerment is striving towards gender parity but at low speed, with multiple challenges and unforeseen hidden agendas, sometimes dissecting more significant cracks in the social spaces. The pandemic COVID 19 has sometimes highlighted such more profound gaps in economic, social, and every day-living area that require newer hand holding of women and more profound healings. These examples have further highlighted that, despite the constant efforts, it is challenging to eliminate gender bias in society. This social phenomenon acts as a significant barrier to the growth of rural and urban women. Even though women are qualified to take up responsibilities, they are withheld from taking higher positions and jobs due to many reasons. However, the silver lining is that now people are talking, writing, discussing, and openly deliberating with new data, mindsets, and movements with 
gender-neutral forms and ways. Gender mainstreaming, gender budgeting, gender auditing are making inroads while formulating policies. The path towards gender parity looks within reach for some, a number more than the previous decade.

With technology's help, gender bias, at least in assessment, is striving towards gender empowerment. Many new applications are getting added. For instance, gender bias in workplaces has been considerably reduced. Organizations now evaluate every individual's performance, irrespective of their gender. Several applications and performance appraisal techniques like Management by Objective, Human Resource/Cost Accounting, etc., made the evaluation process transparent. Despite all these significant changes, women in the field of employment are still underpaid. This holds not only for rural areas but also for urban areas as well, where women's average wages are still considerably lower compared to men's average wages. Also, they are part-time and generally low productive. The current scenario of women is better than before, but a lot more can be done to uplift women who contribute almost half of human resources.

\section{Disclosure statement}

The authors report no conflict of interest.

\section{Acknowledgment:}

**This paper acknowledges the support given to the Project 'Women Empowerment Atlas of India Science Technology Perspective', SEED Division, Science and Technology for Women, from Department of Science and Technology, Ministry of Science \& Technology, Government of India.

\section{References}

[1] Annual Report (2019). Retrieved June 29, 2020, from https://labour.gov.in/sites/default/files/Final_AR_English _21-7-19.pdf

[2] U.N. Retrieved June 29, 2020, from https://www.unwomen.org/en/news/infocus/commission-on-the-status-of-women-2012/factsand-figures

[3] World Bank. 2019. 'Working For Women in India.' Retrieved June 29, 2020, from https://www.worldbank.org/en/news/feature/2019/03/08/ working-for-women-in-india

[4] https://www.britannica.com/topic/Women-in-Science2100321

[5] https://www.statista.com/chart/16970/women-stem/

[6] https://www.nationalgeographic.com/culture/2019/03/par tner-content-empowering-female-farmers/

[7] https://shodhganga.inflibnet.ac.in/bitstream/10603/15356 5/11/11_chapter\%203.pdf

[8] https://spore.cta.int/en/dossiers/article/gender-equalityag-tech-s-potential-to-boost-women-s-empowermentsid0d5c7af0e-a20c-440b-8b48-f6ae9cd7a298

[9] http://www.fao.org/3/am307e/am307e00.pdf

[10] https://www.researchgate.net/figure/Gender-gap-inworkforce-participation-rates-in-Indiapercentages_tbl3_254285022

[11] https://opentextbc.ca/womenintheworld/chapter/chapter1-women-and-poverty/

[12] https://blog.vantagecircle.com/womens-safetyworkplace/

[13] https://www.livemint.com/Opinion/v80I9EwDz6oyklST 8ebqMM/Reversing-womens-decline-in-the-Indianlabour-force.html 